\title{
The use of physical characteristics for predicting nutritive value in breeding material of tall fescue (Festuca arundinacea Schreb.)
}

\author{
A. J. P. van Wijk ${ }^{1}$ and Chr. Paul ${ }^{2}$ \\ 'D. J. van der Have B.V., P.O. Box 1, 4410 AA Rilland, Netherlands \\ ${ }^{2}$ Institut für Grünland und Futterpflanzenforschung, Bundesallee 50, D-3300 \\ Braunschweig, Federal Republic of Germany
}

Received: 4 June 1985; accepted: 10 July 1985

Key words: tall fescue, nutritive value, milling resistance, leaf flexibility, crude fibre, near-infra-red analysis

\section{Summary}

The nutritive value of tall fescue (Festuca arundinacea Schreb.) is low compared to that of ryegrasses (Lolium species). In order to define the characteristics that the breeder can use when selecting for higher quality, the physical characteristics milling resistance and leaf flexibility were determined in 123 varieties of tall fescue. These were set against chemical and vegetative characteristics of the varieties. It was found that milling resistance gave an indication of the physical structure of the whole plant and corresponded with crude fibre content. The data suggest that milling resistance and leaf flexibility were inter-related and that milling resistance could be applied as an objective, relatively simple and low-cost laboratory method for predicting voluntary intake of tall fescue.

\section{Introduction}

Breeding for higher forage quality represents an interesting challenge for plant breeders when cost-effective laboratory methods for estimating individual quality characteristics are available. Numerous past approaches very often consisted of experimental selection work in a range of forage plant species, broadly directed at improving general quality attributes such as digestibility and protein content. As long as such selection programmes are limited to species already high in nutrive value, such as ryegrass (Lolium) species, and if selection response is only obtained at the expense of other agronomical attributes such as forage yield, persistence or seed yield, the resulting variety will be of little practical relevance for the farmer. A better alternative is to concentrate on species with known nutritional deficiencies but of otherwise excellent agronomic performance. 
Tall fescue (Festuca arundinacea Schreb.), a productive forage grass species with a wide adaptation under different climatic conditions, is a species that needs improvement of its nutritive value. The nutritive value, defined as the product of voluntary intake, digestibility and the efficiency of utilization of the digested nutrients by the ruminant, of this species is low compared to that of the ryegrasses.

The literature is not unanimous as to which factor must be held responsible for the low nutritive value of tall fescue. Alkaloids, including those released from systemic fungi, have been associated with animal disorders and poor animal performance when tall fescue was offered, especially under North American summer conditions (Bush \& Buckner, 1973). Breeding to reduce alkaloid concentration has been effective since the concentration of perloline, the major alkaloid, proved to be highly heritable (Buckner et al., 1973). Feeding experiments for elucidating the role of perloline, however, have not given conclusive answers as to the anti-nutritive potential of this compound (Carlier et al., 1983).

From a feeding experiment where dairy cows were fed with freshly cut grass of tall fescue, perennial ryegrass (Lolium perenne $\mathrm{L}$.) and Italian ryegrass (L. multiflorum Lam.), Luten \& Remmelink (1984) concluded that differences between species in net energy content were only small, while intake and milk production from tall fescue were clearly lower than from the ryegrasses. Therefore, differences in intake could not be attributed to differences in digestibility - these could be caused by the rate at which the digesta leave the rumen. The latter may be related to the amount and structure of the less readily digestible part of the grass, the cell wall, which in turn is related to the physical structure of the forage. Its expression in terms of leaf flexibility was indeed found to be related to forage intake for various tall fescue strains (Gillet \& Jadas-Hecart, 1965; Jadas-Hecart, 1982).

Such physical characteristics can be of aid to the plant breeder when screening for nutritive value in large plant populations in the field. A quick laboratory test for assessing another physical plant characteristic called fibrosity index, was originally devised by Chenost (1966). It demonstrated that the energy consumption of a mill during the grinding of coarsely chopped forages was related to their voluntary intake by sheep. Laredo \& Minson (1973) and Jones et al. (1974) confirmed this finding. Also, Paul \& Mika (1981) and Badoux \& Scehovic (1983), working with modified techniques, found close correlations between fibrosity index and cell wall characteristics.

The aim of this study was to establish relationships in tall fescue between the physical characteristics, milling resistance as described by Paul et al. (1981) and leaf flexibility, with vegetative and chemical characteristics, in order to define the traits that the breeder could use when selecting for quality.

\section{Material and methods}

In August 1980, 123 experimental and standard varieties of tall fescue were sown in 3 replicates on sandy soil near Bergen op Zoom, Netherlands. The seed rate used was $50 \mathrm{~kg} / \mathrm{ha}$. Plots composed of 10 rows at a distance of $12.5 \mathrm{~cm}$ were of $8 \mathrm{~m}^{2}$ size. The varieties were grouped according to maturity: early, intermediate and late 
heading, consisting of 32,64 and 27 varieties respectively.

Yield of fresh matter was determined from 1981 to 1984 in a varying number of cuts per year. In February/March of each year and after each cut $80 \mathrm{~kg} \mathrm{~N} / \mathrm{ha}$ was applied.

In 1982, date of head emergence (HD) of each individual plot was determined as the date at which flowering heads were evenly distributed over the plot. HD was expressed as the number of days after 1 April.

In 1983 yield of fresh matter (Y FM) per plot was determined on 3 June (first cut) and on 2 September (third cut). The plots of replicate one were sampled. Prior to cutting stemminess (ST) and leaf flexibility (LF) were estimated on a 1-9 scale ( $1=$ no stems present, flexible leaves; $9=$ many stems present, rigid leaves).

The samples were dried at $100{ }^{\circ} \mathrm{C}$ and chopped to a theoretical length of $0.5 \mathrm{~cm}$. All samples were analysed for milling resistance (MR) according to Paul et al. (1981) and for crude fibre content (CF) at the Institut für Grünland and Futterpflanzenforschung, Braunschweig.

Near-infra-red (NIR) reflectance spectroscopy was applied to estimate the content of cellulose (C), the in-vivo digestibility (D) and voluntary intake (VI). The NIR instrument used was a Technicon Infralyzer 400, which was calibrated for tall fescue forage quality by means of samples, supplied by the Station de Haute Belgique, Libramont-Chevigny, Belgium.

Correlation and regression analysis was applied for determining the numerical association between the characteristics measured in the field and in the laboratory.

\section{Results}

The tall fescue material studied had a wide genetic diversity. Next to the experimental varieties, developed from French, Spanish and American germplasm sources, commercially available varieties from EEC countries and from the USA were included. Among the latter ones Mediterranean and turf types occurred. HD varied to a great extent between the three maturity groups, but within groups this variation was not as pronounced. Average HD for the 32 early varieties was 19 May with a range from 14 to 25 May. The 64 intermediates had an average HD of 23 May (varying from 14 to $29 \mathrm{May}$ ), while the mean of the 27 late varieties was on average three days later than that of the intermediate varieties (range from 22 to 31 May).

Differences in herbage yield between varieties occurred as well. Measured over a four year period the highest and lowest fresh matter yield of the early, interme-

Table 1. Means and standard deviations of milling resistance (MR), leaf flexibility (LF), crude fibre content (CF) and yield of fresh matter (Y FM).

\begin{tabular}{|c|c|c|c|c|c|c|c|c|}
\hline \multirow[t]{2}{*}{ Cut } & \multicolumn{2}{|c|}{$\mathrm{MR}\left(\mathrm{Wh} 10^{-2 / 5} \mathrm{~g}\right)$} & \multicolumn{2}{|l|}{ LF } & \multicolumn{2}{|c|}{$\mathrm{CF}(\%)$} & \multicolumn{2}{|c|}{ Y FM (t/ha) } \\
\hline & Mean & SD & Mean & SD & Mean & $\mathrm{SD}$ & Mean & SD \\
\hline $83-06-03$ & 21.7 & 3.4 & 6.6 & 1.5 & 36.1 & 1.7 & 37.1 & 4.4 \\
\hline $83-09-02$ & 17.0 & 2.2 & 6.7 & 1.6 & 29.6 & 1.2 & 18.5 & 2.0 \\
\hline
\end{tabular}


diate and late heading group differed 19,34 and $18 \%$ respectively. Differences in herbage yield therefore especially existed within the intermediate group.

In Table 1 the means and the standard deviations of MR, LF, CF and Y FM are presented. The differences in MR between cuts were associated with corresponding differences in CF and Y FM. As LF was observed on a relative scale within cuts, the differences in MR were not reflected in the LF values. The first cut in 1983 was taken prior to or at head emergence and therefore contained a high proportion of stems. The september cut in 1983 was taken after a dry period, during which the grass had become fibrous. A large variation for all characteristics between varieties occurred.

In Fig. 1 the relationships between MR and CF for both cuts are shown. The correlation coefficients between MR and CF were highly significant, with the correlation coefficient of the first cut being noticeably higher than that of the third. A quadratic regression model showed a better fit to the first cut data than a linear model. This was not the case for the third cut data. The standard deviations of the regressions were of similar magnitude. The fact that two separate regression functions were necessary for characterizing the two cuts indicated that the relationship between MR as a physical character and a CF as a chemical parameter was dependent on alterations in morphology of primary versus secondary growth.

The relationship between the physical characteristics MR and LF and plant characters for the two cuts is given in Table 2 . When quality comparisons between varieties with a different growth rhythm are made at a given date, relationships between quality and plant characteristics are bound to reflect the correlation with growth rhythm. HD showed a significant negative correlation with MR and LF in both cuts,

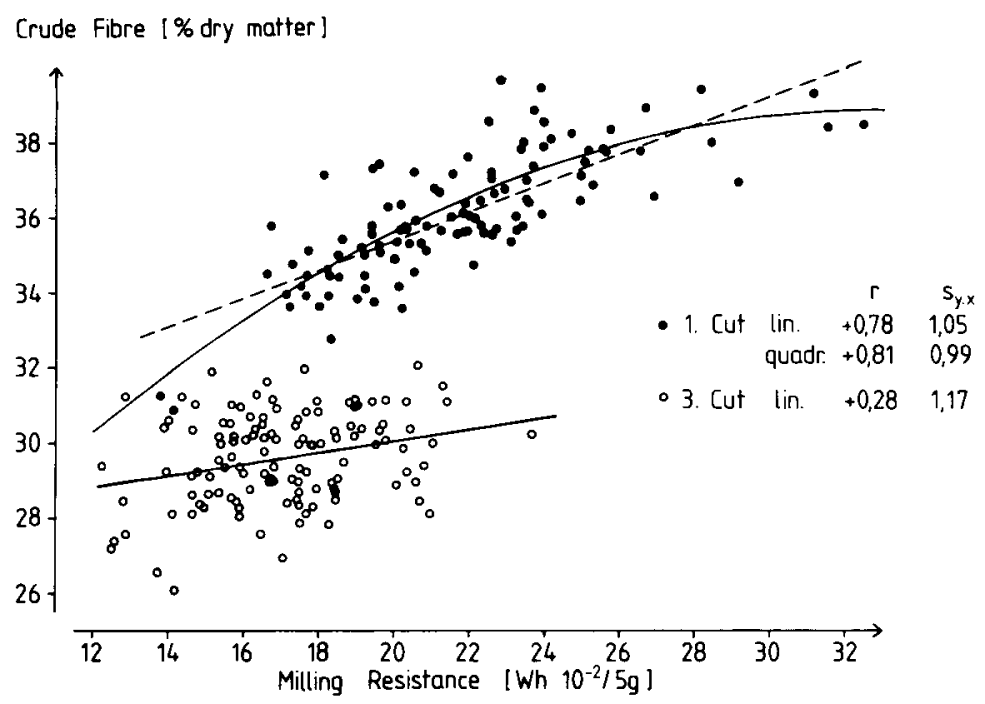

Fig. 1. The relationships between milling resistance and crude fibre. 
Table 2. Linear correlation coefficients of milling resistance (MR) and leaf flexibility (LF), with heading date (HD), yield of fresh matter (Y FM), stemminess (ST) and crude fibre content (CF).

\begin{tabular}{|c|c|c|c|c|}
\hline & \multicolumn{2}{|l|}{ MR } & \multicolumn{2}{|l|}{ LF } \\
\hline & $83-06-03$ & $83-09-02$ & $83-06-03$ & 83-09-02 \\
\hline HD & $-0.23^{*}$ & $-0.33^{* *}$ & $-0.49^{* *}$ & $-0.45^{* *}$ \\
\hline Y FM & $0.30^{* * *}$ & $0.27^{* *}$ & -0.02 & $0.19^{*}$ \\
\hline ST & $0.26^{* *}$ & $-0.19^{*}$ & 0.05 & 0.09 \\
\hline $\mathrm{CF}$ & $0.79^{* *}$ & $0.29^{* *}$ & 0.12 & 0.12 \\
\hline
\end{tabular}

${ }^{*} P<0.05 ;{ }^{* *} P<0.01$.

Table 3. Correlation coefficients of crude fibre content (CF), milling resistance (MR) and leaf flexibility (LF) with cellulose content (C), in-vivo digestibility (D) and voluntary intake (VI).

\begin{tabular}{|c|c|c|c|c|c|c|}
\hline & \multicolumn{2}{|l|}{$\mathrm{CF}$} & \multicolumn{2}{|l|}{ MR } & \multicolumn{2}{|l|}{$\mathrm{LF}$} \\
\hline & $83-06-03$ & $83-09-02$ & 83-06-03 & $83-09-02$ & $83-06-03$ & $83-09-02$ \\
\hline $\mathrm{C}$ & $0.68^{* *}$ & $0.58^{* *}$ & $0.67^{* *}$ & $0.30^{* *}$ & $0.24^{*}$ & 0.15 \\
\hline D & $-0.59^{* *}$ & $-0.62^{* *}$ & $-0.56^{* *}$ & $-0.29^{* *}$ & $-0.35^{* *}$ & -0.13 \\
\hline VI & $-0.72^{* *}$ & $-0.45^{* *}$ & $-0.64^{* *}$ & -0.16 & $-0.19^{*}$ & -0.09 \\
\hline
\end{tabular}

${ }^{*} P<0.05{ }^{* *} P<0.01$.

which meant that early heading varieties had more rigid leaves and possessed a higher proportion of stems than late heading varieties. There was no correlation however between LF and ST pointing to the independence of observation of both characteristics. High-yielding varieties had a higher MR than low-yielding varieties, with none or barely significant differences in LF between the two groups. It should be pointed out that LF, in contrast to MR, was not significantly correlated with CF. In the first cut of 1983 a higher proportion of stems increased MR, which corroborated the relationship between MR and HD. In the third cut this correlation was reversed: ST had a negative correlation with $\mathrm{MR}$, which meant that the more stemmy varieties had a lower MR. At that time of the year the proportion of stems was small and apparently leaves, after a period of drought, were more dry and tough, giving more resistance to milling. For the correlation between CF and ST the same tendencies existed (correlations not shown).

In Table 3 the correlation coefficients of CF, MR and LF with quality characteristics estimated by NIR analysis are shown. Correlation coefficients were mostly higher for the first cut than for the third. In most cases MR and CF correlations remained significant in both cuts, while correlations with LF were only significant in the first cut. Generally, CF showed a better association with NIR-predicted quality parameters than MR, which again seemed more reliable than LF. 


\section{Discussion}

When reviewing laboratory methods for the determination of nutritive quality in forages, Minson (1981) concluded that less emphasis should be placed on chemical analyses, but more attention should be paid to the physical factors in pasture plants. In view of the results obtained by Jadas-Hecart (1982) and previous work at the INRA, Lusignan, France this demand seems to be valid for tall fescue.

In plant breeding programmes suitable sets of forage samples with known VI, which could serve for reference purposes, are hardly available. Indirect methods as a measure for VI therefore have to be applied. One way of testing their reliability may then consist of analysing the degree to which such indirect methods correspond with more readily known methods. In the work presented here, MR and LF as indirect physical methods for estimating VI were set against CF content and NIR analysis. The latter has also proved to be of potential in the prediction of VI (Eckman et al., 1983).

The tall fescue varieties studied displayed a wide variation and had different growth rhythms as can be taken from the maturity and herbage yield data presented. As the varieties were harvested on the same date, irrespective of their particular developmental stages, the variation in quality characteristics encountered was connected with differences in growth stages, masking possible genetic differences in nutritive value. On the other hand, when comparing methods of quality evaluation, a wide range of variation, both genetical and environmental in origin, is advantageous.

The degree of correspondence between MR and CF (see Fig. 1) achieved in the first cut of this study was of similar magnitude as that reported by Borstel et al. (1983) for forage quality variation due to environmental effects and by Badoux \& Scehovic (1983) for genetic effects on tall fescue. It should be pointed out that in comparisons of this kind the correlation coefficient cannot be judged as the only critical indication of method suitability. This is much better fulfilled by the standard error of the regression, i.e. the spread around the regression line. In spite of the considerably lower correlation coefficient between MR and CF in the third cut compared to the first cut (see Fig. 1), the standard error of the regression was only slightly inferior to that of the first cut.

As is evident from Table 2, primary/secondary growth differences had a larger influence on LF than on MR. On the other hand, MR is correlated with ST, which is not the case with LF. Taking these two aspects together, selection for LF alone could lead to a correlated response in $\mathrm{HD}$, whereas selection for low MR alone would lead to a negative correlated response in the ability to produce stems, adversely affecting seed productivity.

Contrary to expectation, LF proved not to be correlated with CF, possibly indicating that LF describes physical mechanical properties of the leaves alone. MR on the other hand was clearly associated with CF (see Fig. 1), giving an indication that this characteristic is relevant to the physical, mechanical structure of the whole plant.

These results point to the risk of selecting for either of the two characteristics, as 
they may lead to undesired, correlated responses. As a possible solution leaf and stem properties can be determined in conjunction with leaf/stem ratio. The question would then have to be whether LF as a subjective assay should be replaced by an objective test like leaf tensile strength determination. Alternatively a separate determination of MR on leaves and stems could be carried out.

The value of LF should not be underestimated, however. It is a cheap and simple test available to any plant breeder. In this study ten varieties from the French Variety List of 1978 (Anonymous, 1979) were included. The Variety List gives for these ten varieties ratings for leaf flexibility, ranging from flexible to very rigid. These ratings were transferred to the $1-9$ scale. The correlation coefficient between these values and the MR data for the first and the third cut were 0.62 (NS) and $0.73(P<$ $0.05)$ respectively. These correlations suggest that MR and LF are inter-related and that MR might be applied as an objective test for estimating VI in tall fescue. Moreover, compared to CF determination, MR measurements are relatively cheap and simple to apply, for which no chemical laboratory outfit is required.

When NIR predicted quality characteristics are considered a clear ranking of predictive ability emerged (see Table 3 ): CF being the most and LF being the least suitable. It must remain open as to whether this was caused by the way the NIR system was calibrated.

In this study the possible improvement of the nutritive value of a grass species from temperate areas was investigated. Tropical grasses with their continuous stem elongation under high levels of radiation and temperature lignify much faster than temperate species. Consequently, the detioration of tropical grasses in nutritive value is more marked. The prime field of application of the physical methods discussed in this study for improving nutritive should therefore be in tropical grasses in the tropics.

\section{References}

Anonymous, 1979. Bulletin des Variétés. Plantes fourragères. INRA, Editions SEI, Versailles.

Badoux, S. \& J. Scehovic, 1983. Le test de fibrosité, une méthode de sélection pour la qualité fourragère de la fétuque élevée et des hybrides Lolium x Festuca. Recherches Agronomiques Suisse 22: 61-70.

Borstel, U. von, Chr. Paul \& M. Sommer, 1983. Mahlwiderstandsmessungen an Rauhfutter. IV. Einsatz in der Futterbauberatung. Landbauforschung Völkenrode 33: 251-258.

Buckner, R. C., L. P. Bush \& P. B. Burrus II, 1973. Variability and heritability of perloline in Festuca sp., Lolium sp. and Lolium-Festuca hybrids. Crop Science 13: 666-669.

Bush, L. P. \& R. C. Buckner, 1973. Tall fescue toxicity. In: A. G. Matches (Ed.), Antiquality components of forages. Crop Science Society of America, Madison, p. 99-112.

Carlier, L. A., A. P. Andries \& G. A. van Bogaert, 1983. L'alcaloide perloline dans les graminées en tant que composant antiqualitatif pour le bétail bovin. Revue de l'Agriculture 36: 1493-1505.

Chenost, M., 1966. Fibrousness of forages: its determination and its relation to feeding value. Proceedings 10th International Grasland Congress, p. 406-411.

Eckman, D. D., J. S. Shenk, P. J. Wangsness \& M. O. Westerhaus, 1983. Prediction of sheep responses by Near Infrared Reflectance Spectroscopy. Journal of Dairy Science 66: 1983-1987.

Gillet, M. \& J. Jadas-Hecart, 1965. Leaf flexibility, a character for selection of tall fescue for palatability. Proceedings 9th International Grassland Congress, Vol. 1: 155-157.

Jadas-Hecart, J. 1982. Etude en pature de l'appétibilité de fétuques élevées (Festuca arundinacea Schreb.) à l'aide de moutons. Agronomie 2: 487-492. 


\section{A. J. P. VAN WIJK AND CHR. PAUL}

Jones, D. I. H., R. J. K. Walters \& E. L. Breese, 1974. The evolution of herbage breeding programmes for improved voluntary intake and other nutritive characteristics. Proceedings 5 th General Meeting European Grassland Federation (Växtodling, 1973) 29: 111-120.

Laredo, M. A. \& D. J. Minson, 1973. The voluntary intake, digestibility and retention time by sheep of leaf and stem fractions of five grasses. Australian Journal of Agricultural Research 24: 875-888.

Luten, W. \& G. J. Remmelink, 1984. Opname van Engels raaigras, rietzwenkgras en Italiaans raaigras door melkvee. [Intake of perennial ryegrass, tall fescue and Italian ryegrass by dairy cattle]. PR Report No 97; $72 \mathrm{pp}$.

Minson, D. J., 1981. An Australian view of laboratory techniques for forage evaluation. In: J. L. Wheeler \& R. D. Mochrie (Eds.), Forage evaluation: concepts and techniques, AFGC/CSIRO, p. 57-73.

Paul, Chr. \& V. Mika, 1981. Mahlwiderstandsmessungen an Rauhfutter. II. Beziehungen zwischen Mahlwiderstand und Futterwertmerkmalen. Landbauforschung Völkenrode 31: 163-169.

Paul, Chr., G. J. Schild \& H. Honig, 1981. Mahlwiderstandsmessungen an Rauhfutter. I. Apparative Voraussetzungen. Landbauforschung Völkenrode 31: 7-10. 